\title{
THE PHENOMENON OF GREEN TRADE PROTECTIONISM: ANALYSIS OF THE EU PALM OIL IMPORT BAN IN THE ASEAN REGION
}

\author{
Maretha Syawallin Umarach \\ Universitas Muhammadiyah Yogyakarta \\ Email: marethaallin@gmail.com
}

ARTICLE HISTORY

Received:

25 January 2021

Revised

17 June 2021

Accepted:

03 July 2021

Online available:

20 November 2021

Keywords:

Green trade

protectionism, Renewable Energy

Directive (RED),

European Union,

ASEAN, crude palm oil (CPO).

\section{ABSTRACT}

Introduction: The policy issued by the European Union is the Renewable Energy Directive (RED) that turn creates barriers to palm oil exports from other countries to the European Union. The policy to ban palm oil under the pretext of protecting the environment is considered to be a new obstacle to trade. One of the rejection responses came from the ASEAN region. However, even though it has received a lot of protests and rejections, until 2020 the European Union has not changed its policy regarding the ban on the use of palm oil for biodiesel in the European region.

Methods: This article focuses on the reasons for the European Union implementing protectionism policies towards the Palm Oil sector in the ASEAN region. The explanation regarding this focus is explained using the Neo Mercantilism approach.

Results: The policy to ban palm oil imports can be analyzed to respond to the EU's ambition and concern that the climate emergency will jeopardize the trade process in the future. The European Union research group considers that oil palm plants have a high contribution to the problem of deforestation and forest and peatland diversion in the world, especially ASEAN. Howeever, it can also be seen that there are ambitions to protect the domestic production of biofuels from the EU sunflower and radishes from global competition. The above concerns and motivations then prompted the European Union to formulate protectionism for regional economic stability.

Conclusion and suggestion: ASEAN, especially Indonesia and Malaysia, have become quite vocal actors in responding to this policy. Indonesia and Malaysia are the biggest contributors of palm oil exports to Europe. As well as causing an oversupply of global palm oil supplies, this policy is considered to discriminate against and violate free-trade norms. 


\section{INTRODUCTION}

Nowadays environmental problems have become a special concern for the international world. Environmental problems are a problem for all countries in the world, this is because a country, either directly or indirectly, affects the environmental conditions of other countries. This is undeniable considering that every day countries in various parts of the world carry out industrial activities in order to compete to produce the best products to be sold in the global market as well as in their own countries. This fact shows that the world's environmental conditions will be increasingly influenced by trade in line with efforts to liberalize global trade (Arfani, 2012).

The growing issue that the trade industry process is one of the factors of environmental emergency, encourages countries in the world to formulate a trade policy that is friendly to climate change and the environment. Green trade protectionism then became a new phenomenon as a form of state response to environmental emergency issues. The purpose of green protectionism is the act of protecting oneself from the products of other countries by reason of the application of sustainability criteria. Green protectionism is not about environmental policy itself, but about adding nonenvironmental objectives that are discriminatory, or overly trade restrictive in intent and / or effect, to environmental policy (Erixon, 2009).

Against the background of the pressure from the influence of the green party in the electoral sector as well as the big concern about environmental degradation, the European Union is one of the entities that massively integrates environmental issues in trade policy. The European Union is even optimistic that it will become the first neutral continent in 2050 and become the most environmentally conscious government. This spirit is then implemented in a draft "Green New Deal" which aims to integrate economic, regulatory, competition and trade policies to help the environment (Beattie, 2019).

One of the policies issued by the European Union is the Renewable Energy Directive (RED). RED was first enacted on June 2, 2009 as a primary arrangement used to regulate biofuel use. RED is a way for the European Union to ensure that their energy supply is safe and capable of reducing carbon emissions from greenhouse gases by replacing fossil fuels with renewable fuels such as biofuels (Wahyudi, 2019). In early January 2018, the European Parliament amended the draft RED to include a ban on the use of palm oil biofuels in Europe. The following prohibition is based on the fact that palm oil production is not environmentally friendly, cuts down trees, destroys ecosystems and biodiversity. This European Union step is certainly a good start to reduce one of the many environmental problems in the world. But on the other side, this step is actually a new obstacle in the global market. The RED policy makes the EU have a reason

Published by University of Airlangga.

This is an open access article under the CC BY SA license (https://creativecommons.org/licenses/by-sa/4.0/) 
to protect itself from biofuel products from other countries, the EU's action to protect itself through the implementation of RED is considered a form of green protectionism. With the implementation of this RED, the European Union hopes that its member countries can set targets in using renewable energy and set criteria that allow biofuels to be counted below the renewable energy targets. This hope, of course, is not something that is impossible to realize considering that EU member states have the ability to produce their own renewable energy. The European Union is indeed one of the leaders in developing technology to produce renewable energy (Dewi, 2013).

However, in practice the EU policy caused controversy in the international realm. The policy to ban palm oil under the pretext of protecting the environment is considered to be a new obstacle to trade. One of the rejection responses came from the ASEAN region, especially Indonesia and Malaysia, which are the main exporters of palm oil for countries in the European region. From an economic point of view, the European Union's plan to develop its renewable energy will create new markets for these countries. However, herein lies the obstacle, the implementation of RED by the European Union will become a problem if the vegetable oil exporting countries cannot meet the standards applied by the European Union related to sustainability issues (Dewi, 2013). The implementation of RED received protests from palm oil exporting countries to Europe, especially when the policy was renewed and ratified to RED II, where in RED II 28 EU countries agreed that palm oil was not included in the sustainable category so it could not be used for biodiesel. European countries argue that this decision was based on the problem of forest destruction (deforestation) caused by massive oil palm cultivation activities. This latest policy will take effect in 2024 and is planned to take effect in total in 2030 (BBCNews, 2019).

As a country that is one of the exporters of palm oil in the European region, Indonesia has shown a resistance. In 2019, Indonesia drafted a draft to bring this issue to the World Trade Organization. At that time, the Director General of Indonesian Foreign Trade, Oke Nurwan, emphasized that the steps taken by Indonesia were a continuation of resistance from Indonesia after diplomatic steps taken previously had not worked. Not only the government, Indonesian non-government parties also showed their resistance. GAPKI or the Indonesian Palm Oil Entrepreneurs Movement through its representative, Bambang Aria, said that his party fully supports the Indonesian government's action against the EU policy. Then Malaysia, which is also a palm oil exporting country to Europe, has also moved since 2015 to resolve this problem. However, even though it has received many protests and rejections, until 2020 the European Union has not changed its policy regarding the ban on the use of palm oil for biodiesel in the European region (BBCNews, 2019). Protection of the environment is still the main focus of the European Union in implementing its policies. Through the following research, the authors will 
conduct an analysis related to the phenomenon of green trade protectionism and the EU's protectionism policies on the Palm Oil trade sector and its impact on the ASEAN region.

\section{LITERATURE REVIEW}

Some several studies or articles discuss the European Union's attitude in imposing protectionism in several sectors based on protecting the environment. First, the journal entitled Green Trade Protectionism: An Analysis of Three New Issues that Affect Developing Countries by Maria Victoria Loticci (Lottici, 2014) explains that nowadays, the environment is increasingly being used to justify protectionist actions. The author emphasizes three developing issues, namely green growth and green economy, climate change response actions, and liberalization of environmental goods and services. These issues are used to impose barriers to goods and services originating from developing countries to increase export market access for developed countries' industrial products. Although environmental protection is a legitimate goal, this should not lead to the adoption of protectionist policies that impose hidden restrictions or unilateral discrimination in the international trade process.

Next is the journal entitled The Green Side of Protectionism: Environmental Concerns and Three Facets of Trade Policy Preferences by Michael M. Bechtel (Bechtel, 2010). The authors state that free trade's expected environmental consequences play an essential role in an entity's protectionist attitude. The author examines the phenomenon of ecological problems that play a crucial role in how individuals evaluate international economic exchanges. The authors found that individuals with strong environmental concerns tend to have a pessimistic view of globalization. These individuals are also more selective in evaluating foreign products based on criteria beyond price and quality.

In an article written by Carolyn Fischer and Timothy Meyer entitled Baptist and Bootleggers in the Biodiesel Trade: EU - Biodiesel (Indonesia), the author explains that the European Union government plans to fight the impact of Indonesia's oil palm oil export tax using anti-dumping duties, but the refusal is rejected. by the Dispute Resolution Agency. The decision by the EU to use anti-dumping duties is the latest step they are taking in a dispute over the renewable energy market. The article states that Indonesia and the European Union have intervened in their markets in the context of developing the domestic biodiesel industry. The request of the European Union to impose import duties on Indonesian biodiesel is inelastic, causing many polemics between the two countries (Fischer \& Meyer, 2020).

Then, Windratmo Suwarno wrote an article related to this topic with the title Kebijakan Sawit Uni Eropa dan Tantangan bagi Diplomasi Ekonomi Indonesia. In this 
article, the author explains that starting from the formation of the EU Parliamentary Resolution policy on palm oil management and rainforest deforestation, it poses a big challenge to the Indonesian palm oil industry. In his article, it was stated that the policy issued by the European Union contained political motives and business competition in the palm oil industry. The Indonesian palm oil industry itself is in line with the goals of sustainable development and in accordance with international protocols. Indonesia considers this a form of discrimination, so it feels the need to set a strategy in dealing with this. This paper explains how Indonesia's economic diplomacy is being carried out by its efforts to face the European Union in suppressing imports of palm oil (Suwarno, 2019).

Furthermore, the article written by Jefferson $\mathrm{Ng}$ who also discusses the topic of palm oil is entitled EU's Palm Oil Challenge: How Should Singapore Respond? In this article, the authors outline the possibility of what the European Union will do to the palm oil commodity, namely that it will periodically eliminate the use of palm oil biofuel. However, it will have a bad impact on Indonesia because Indonesia is the largest palm oil producer in the world. The author states that this has an impact on the diplomatic relations between ASEAN and the European Union (Jefferson, 2019).

Hanna Deringer and Hosuk Lee-Makiyama have written an article entitled Europe and South-East Asia: Shifting from Diplomacy to Unilateralism. In his article, he discussed the improvement of strategic partnership relations between ASEAN and the European Union which was delayed due to a dispute over a policy issued by the European Union which stated that it would remove palm oil biofuel from the European Union market. ASEAN member countries show their objection to this matter and consider the decision of the European Union to be a form of discrimination for palm oil producing countries, where the largest palm oil producer, namely Indonesia and Indonesia are ASEAN member countries. Indonesia plans to report this issue to the WTO ,. It was stated in the article that the exclusion of one of the plants was not in accordance with the laws established by the WTO (Deringer, 2019).

And then, an article written by RA Arief, AR Cangara, MN Badu, A Baharuddin and A Apriliani entitled The impact of the European Union's (EU) Renewable Energy Directive Policy on the Management of the Indonesian Palm Oil Industry discusses the interests of the European Union towards policies implemented in renewable energy namely to protect the environment as well as protect palm oil in the European Union. However, the policy they have implemented has a negative impact on Indonesia's palm oil exports, this policy is a form of green protectionism that applies non-tariff protection. The author in his article proves that there have been changes to Indonesian palm oil production after the adoption of the Renewable Energy Guidelines in the European Union (Arief, 2020). 


\section{RESEARCH METHODS}

In explaining the application of the EU's protectionism policies to the ASEAN Palm Oil trade sector, the author will use the Neo Mercantilism approach. In explaining, Neo-Mercantilism actually cannot follow the direct approach of mercantilism. Mercantilism arrived in Europe in the 16th century to promote governance over a country's economy. Mercantilism believes that the welfare of a nation comes from reserves or the storage of precious metals. So that for countries that do not have adequate access to added, precious metals can be obtained through trade. The trade balance must be profitable, with the value of exports must exceed the value of imports. Although it has stated a role for the state, mercantilism provides minimal guidance. Along with the development of international dynamics and the massive influence of democracy, the mercantilism approach began to be abandoned and shifted to a more liberal approach. The global environment has already started to believe in free markets and a more open economy without intervention from the state. Still, on the other hand, state intervention in practice cannot be eliminated so that the concept of NeoMercantilism emerged, which described the nationalist actions of the state during the open market era (Hettne, 1993).

Neo-mercantilism depicts various governments' efforts in today's world of interdependent international political economy to monitor their respective national industries to gain a comparative advantage. The state carries out intervention as a step to accumulate and maintain wealth and power. Gilpin, in his writings, explains that neomercantilism has several core thoughts. First, the nation-state remains the dominant actor in both the local and international economy. Gilpin believes that the global economy is the result of interactions between countries and markets. State intervention in the economy is justified based on achieving national interests. These interventions can be seen from the actions of assistance, regulation, and protection of specific industries. Neo mercantilism considers that intervention or even protection is needed to increase exports and minimize imports (Gilpin, 1987).

Second, competition between countries to increase exports. Competition is carried out as a state effort to increase exports to impact foreign exchange income that a government wants to achieve. Third, regionalism represents the state's cooperative efforts to promote international economic and political goals. Neo-mercantilism believes that regional agreements are a form of representation of state cooperation efforts to promote a country's economic or political purposes. Fourth, economic activity is determined by the market and the socio-political norms or values that exist within a nation's society. In this case, neo-mercantilism explains protectionism as a form of 
political opposition to trade liberalization. Protectionism policies are formulated to face and prevent the free trade process (Gilpin, 1987).

Protectionism itself is defined as a form of a policy deliberately formulated by the government to protect domestic producers from trade competition from outside or the international scope. The policy, which aims to preserve and encourage the national industry, is implemented by applying the tariff or tariff barriers (TF) policy and the Nontariff Barries (NTB) policy. The Tariff Barrier is implemented with countervailing duty, anti-dumping, and surcharge duties. Meanwhile, the Non-tariff Barrier can be seen through the prohibition, quota system, technical provisions, custom value, and health/quarantine regulations. Free trade followers think that trade protectionism is a policy that impacts the inefficiency of resource use and increases import prices that harm consumers at large. (Wahab, 2013, hal. 27).

\section{RESULT AND ANALYSIS}

The motivation of the European Union in implementing protectionist policies towards the palm oil sector: Neo-mercantilism perspective

Neo-mercantilism explains nation-building and state intervention's main role to encourage economic growth in new industries, as explained in the theory section. Neomercantilism emphasizes aspects of nationalism in political and economic thought and practice. The European Union's attitude in issuing the Renewable Energy Directive (RED) decision that then encourages indications regarding the ban on palm oil can be articulated as a form of the role of the state through the European Union in protecting regional economic stability. Two fundamental reasons have driven the EU's position to formulate a policy to ban Palm Oil imports. First, this is related to concerns over environmental emergency issues that are feared to damage the future trade process (Russell, 2020).

The European Union indicates that the expansion of oil palm cultivation has resulted in high deforestation, especially in Indonesia and Malaysia. Increased production encourages the country to open land for new plantations. Scientific studies carried out by the European Commission say that between 2008 and 2011, the expansion of oil palm lands led to $4,300 \mathrm{~km} 2$ of deforestation worldwide. In 2019, the fact stated that oil palm plantations had become the biggest cause of deforestation in Indonesia. Approximately a quarter of permanent forest clearing in Indonesia occurred between 2001 and 2016. Peninsular Malaysia, Kalimantan, and Sumatra are estimated to have 14.7 million hectares of peatlands, indicating that 3.1 million hectares of peatlands have been converted into oil palm plantations. In 2015. Land conversion to expand oil palm plantations has caused environmental problems, including deforestation of peat 
swamps, drainage, and fires. Land clearing by burning is estimated to impact increasing emissions between 207 and 650 tonnes of carbon per hectare (Barthe, 2018).

Besides, deforestation is of particular concern to the European Union because it directly impacts the loss of biodiversity. The conversion of tropical forests to agricultural land, plantations, and other uses cause significant species loss, particularly about the loss of habitat for animals such as orangutans and tigers. The reduction of habitat in which they live causes the effect of extinction of forest animals, which impacts the ecosystem system. A scientific study by the European Commission also says that oil palm has less than $20 \%$ of aboveground biomass as much as trees in rainforests and has a lower capacity to sequester carbon dioxide from the atmosphere. Concerns related to the palm oil industry's negative effects are also based on the fact that greenhouse gas emissions come from land conversion and plantation factory activities (Erixon, 2009, hal. 9-11).

It is a moral obligation for the European Union to save the world's power and end globalization. So that RED was formed to reinforce the commitment of the European Union in overcoming environmental problems by using renewable energy sources. The types of renewable energy referred to by the European Union include solar energy, wind, hydropower, hydrothermal and marine energy, biomass, landfill gas, waste gas processing plants, and biogas. Through the requirements set by RED, 27 member states of the European Union and three other countries included in the European economic area, namely Iceland, Lichtenstein, and Norway, are encouraged to adopt the mandatory national target "20-20-20". This target is set to ensure $20 \%$ of renewable energy used in the European Union comes from renewable sources and a $20 \%$ reduction in primary energy use that must be achieved through energy efficiency by 2020 (Barthe, 2018).

Not quite there yet, RED also set a $10 \%$ target for renewable energy in the transportation sector. Renewable energy can come from many sources, but the main source of transportation must come from biofuels. These biofuels must be sustainable to support mandatory targets for renewable energy and be eligible to support the EU economy. A brief overview of biofuels is the use of lower greenhouse gas emissions and thus has renewable properties. RED states the indication of the calculation of the number of gas emissions seen from the extraction and cultivation of raw materials, changes in land use, processing and distribution, and transportation. Furthermore, emission savings can be increased through agricultural management and carbon capture processes (Arie, 2020, hal. 3).

Second, the palm oil import ban policy issue is also related to political economy factors related to strategies to protect the domestic vegetable oil industry from global competition (ISCC, 2018). The policy of prohibiting and restricting palm oil imports is a step to isolate palm oil from the renewable energy sector to benefit other vegetable oils 
that are less competitive in the European Union. Radish and sunflower crops are the main raw materials for vegetable oil production, which play an important role in the European Union's agricultural politics, especially in France, Germany, and Poland (Roda, 2019). However, palm oil, which has a lower price presentation, is the most competitive competitor for the production of rapeseed and sunflower oil in the EU and world markets. The use of CPO (Crude Palm Oil) in the European Union is intended as the main raw material in the transportation sector to produce renewable energy called biofuel. The development of renewable energy carried out by the European Union is a form of its concern in overcoming environmental problems. Of course, the purpose of creating this technology is to overcome energy scarcity by utilizing renewable resources. To produce biofuels, EU countries import CPO from various parts of the world, including countries in the Southeast Asian region (EEAS, 2013). Thus, policies are needed to protect domestic producers from trade competition from outside so that regional economic stability is maintained (Roda, 2019).

Therefore, through RED, which then formulates a ban on palm oil imports, the European Union aims to ensure supply security, competitiveness, and sustainability. RED was formed to reinforce the European Union's commitment to overcoming environmental problems using renewable energy sources. The types of renewable energy referred to by the European Union include solar energy, wind, hydropower, hydrothermal and marine energy, biomass, landfill gas, waste gas processing plants, and biogas (European Commission, 2018).

Based on the perspective of Neo-mercantilism, in responding to the problems and concerns described above, in playing its role, the state will naturally issue policy formulations related to protectionism. The policy that aims to protect and encourage the national industry is carried out through obstacles in applying the tariff barriers (TF) policy and the Non-tariff Barries (NTB) policy. In the European Union case, the EU's protectionism ambitions for the palm oil sector can be seen from the Renewable Energy Directive framework in 2009 (Russell, 2020). RED is designed for the production and promotion of renewable energy sources in the European Union. In 2018, revisions were made regarding the RED work target. The European Union's ultimate goal was to be a global leader in renewable energy and contribute to the European Union to fulfill its emotional reduction commitments under the Paris Agreement (European Commission, 2018).

One of the RED amendment points was to include a ban on the use of palm oil biofuels in Europe after 2021. Discourse on palm oil resolution has begun to be discussed by the European Union Parliament in 2007. The resolution to prevent the palm oil industry is carried out through a single accreditation regulation. For palm oil entering the 
European Union. Furthermore, the European Union will gradually eliminate vegetable oil use that triggers deforest in 2020 (European Commission, 2018).

On the other hand, the development of biofuels cannot be separated from the EU policy itself. The policies in question cover various sectors, from the agricultural sector to the trade sector. In the agricultural sector, the EU policy regulates farmers' subsidies to facilitate the development of biofuel feedstocks. Then in the trade sector, EU policy regulates the export-import regulation of biofuel fuels. These policies are then used as a framework for the European Union to increase biofuel production and strengthen its position as a producer of vegetable oil on the world market. Through the European Commission, the European Union implements a subsidy policy to achieve longterm targets in reducing dependence on fossil oil (Erickson, 2009).

The impact of the green phenomenon of EU Protectionism on the ASEAN Palm Oil Industry

The free trade groups consider that trade protectionism is a policy that impacts the inefficient use of resources and increases import prices that harm consumers at large (Wahab, 2013, hal. 27). Based on the results of the RED II decision by the European Union in July 2018, biofuels that can be imported into the European Union must have an element of sustainability (sustainability). In this case the cultivation of vegetable oil raw materials does not cause negative impacts or damage to the environment. Meanwhile in oil palm plantations, it is necessary to clear land (deforestation), so that oil palm plantations are included in the Indirect Land-Use Change (ILUC) scheme (Deringer, LeeMakiyama, \& Murty, 2019). Moreover, oil palm plantations in Indonesia are deemed not meeting the criteria as "green" plantations in their cultivation. In this case there are many negative issues stating that forest fires that occurred in Indonesia were carried out by interest groups aiming to clear oil palm land (Christiningrum, 2018).

Refusal to import palm oil into the European Union has a huge impact on ASEAN countries that export palm oil, especially Indonesia and Malaysia. Indonesia and Malaysia are the biggest contributors of palm oil exports to Europe. In addition, Indonesia and Malaysia are the largest producers of palm oil in the world at $85 \%(\mathrm{Ng}$, 2019). In Indonesia, palm oil exports are the highest contributor to state revenue, with an export value of around US \$20.58 billion or equivalent to Rp.289 trillion in 2018 . Moreover, Europe is the second largest palm oil importer after India. Therefore, RED II's policy of rejecting imports of palm oil has a major impact on the Indonesian economy (Purba, Sinaga, Novianti, \& Kustiari, 2018).

In addition, the EU's rejection of imports could lead to oversupply of global palm oil supplies. This is because palm oil, which should have been exported to the European Union, was diverted which then led to an accumulation of 46 percent of total palm oil

Published by University of Airlangga.

This is an open access article under the CC BY SA license (https://creativecommons.org/licenses/by-sa/4.0/) 
exports to Europe or around 7.5 million tons of palm oil. If oversupply occurs, there will likely be a correction in the price of palm oil. This will lead to a decrease in palm oil revenues. If the decline in palm oil prices continues, it will cause the closure of the palm oil industry which results in the absorption of palm oil production from farmers. This will put 5.3 million oil palm farmers at risk of losing their jobs and reducing farmers' welfare (Christiningrum, 2018).

From this explanation, the rejection of imports by the European Union greatly affected the Indonesian economy. Acting on the policies imposed by the European Union, ASEAN members especially Indonesia and Malaysia protested strongly against the policy. Indonesia also filed a protest to the World Trade Organization (WTO) over this European Union policy (BPDP, 2018).

\section{Impact on countries in Europe}

To achieve the European Union's target of reducing greenhouse gas effects by $35 \%$, each country in the European Union must achieve a target of using renewable energy of a maximum of $7 \%$ by 2020 (Deringer, Lee-Makiyama, \& Murty, 2019). Of the several types of vegetable oil raw materials, palm oil is the easiest and most efficient vegetable oil raw material to process and produce. But the European Union itself does not have the land to meet biofuel feedstocks. This can be seen in 2012, EU countries need to import as much as $40 \%$ vegetable oil to achieve the biofuel production target of $6.6 \%$. This provides an opportunity for vegetable oil producing countries to meet this demand, especially Indonesia. But on the other hand, with the implementation of the RED II policy, vegetable oil exporting countries must meet the sustainability criteria set by countries in the European Union. Which in several countries in the European Union have different standards. This is seen as a way to reduce imports of palm oil from Indonesia and Malaysia because it is considered threatening and even detrimental to their investment (Dewi, 2013).

As is well known, the European Union is a renewable energy producer which is quite advanced in its development technology. Until recently, the European Union was the largest producer of biodiesel in the world. Since 2005, biodiesel production in the European Union has continued to increase by 20 times. Germany is the largest biodiesel producing country and accounts for nearly half of the total biodiesel produced in the European Union. Germany is more or less capable of producing 2.5 million tons of biodiesel. After Germany, France is the second country in the European Union as the largest producer of biodiesel, which is about 2 million tons. Meanwhile, bioethanol does not really occupy a crucial position like biodiesel, where bioethanol only meets $20 \%$ of the biofuel demand in the European Union. Therefore, biodiesel is a very important requirement for countries in the European Union. Therefore, biofuel producing countries such as Indonesia and Malaysia consider the implementation of RED in the European 
Union as a trade strategy to reduce imports of biofuels (Biodiesel and bioethanol) so that the EU biofuel market is unrivaled (Dewi, 2013).

\section{CONCLUSION}

The phenomenon of green trade protectionism has recently been widely discussed in the international arena to respond to environmental emergencies. As a region that is committed to being a climate-neutral region, the European Union considers the mission to save the world's forests and stop global warming as a moral imperative. The European Union then implemented this ambition into a trade policy, which in fact reflected protectionism and discrimination. In 2009, the European Union promoted the Renewable Energy Directive framework, which was amended again in 2018. The 2018 amendments reinforce the EU's mission to become a global leader in renewable energy. One of the points discussed in the amendment was to include a ban on palm oil biofuel in Europe.

From the perspective of neo-mercantilism, the policy to ban palm oil imports can be analyzed to respond to the EU's ambition and concern that the climate emergency will jeopardize the trade process in the future. Not to mention, the European Union research group considers that oil palm plants have a high contribution to the problem of deforestation and forest and peatland diversion in the world, especially ASEAN. However, from the perspective of neo-mercantilism, it can also be seen that there are ambitions to protect the domestic production of biofuels from the EU sunflower and radishes from global competition. The above concerns and motivations then prompted the European Union to formulate protectionism for regional economic stability. ASEAN, especially Indonesia and Malaysia, have become quite vocal actors in responding to this policy. Indonesia and Malaysia are the biggest contributors of palm oil exports to Europe. Besides, Indonesia and Malaysia are the largest producers of palm oil in the world. As well as causing an oversupply of global palm oil supplies, this policy is considered to discriminate against and violate free-trade norms.

\section{REFERENCES}

Arfani, R. N. (2012, March 1). Praktek New-Protectionism dalam Perdagangan Dunia: Pemanfaatan Isu Lingkungan dalam Perdagangan Kayu Indonesia-Amerika Serikat. MONOGRAPH SERIES:, p. 1.

Arie, R. A. (2020). The impact of the European Union (EU) renewable energy directive policy on the management of Indonesian palm oil industry. IOP Conference Series: Earth and Environmental Science, 1-7.

Arief, R. A. (2020). The impact of the European Union (EU) renewable energy directive policy on the management of Indonesian palm oil industry. IOP Conference Series: Earth and Environmental Science. 
Barthe, M. (2018). Study on the environmental impact of palm oil consumption and on existing sustainability standards. Brussels: European Commission, DG Environment .

BBCNews. (2019, March 23). Kelapa sawit, ancaman perang dagang RI-Uni Eropa dan enam hal lainnya. Retrieved December 2020, from BBC News: https://www.bbc.com/indonesia/indonesia-47663602

Beattie, A. (2019, Desember 11). Is the EU's green policy protecting the planet or European industry? Retrieved Januari 12, 2021, from Financial Times: https://www.ft.com/content/0432eb26-15f2-11ea-9ee4-11f260415385

Bechtel, M. M. (2010). The Green Side of Protectionism: Environmental Concerns and Three Facets of Trade Policy Preferences . Review of International Political Economy, 1-30.

BPDP. (2018, Nov 19). Indonesia Files Complaint Over RED II in WTO. Retrieved Januari 23, 2021, from bpdp.or.id: https://www.bpdp.or.id/en/Indonesia-FilesComplaint-Over-RED-II-in-WTO

Christiningrum, R. (2018, Februari). Dampak Pelarangan Ekspor Sawit ke Uni. BULETIN $A P B N, 3-8$.

Deringer, H. (2019). Europe and South-East Asia: Shifting from Diplomacy to Unilateralism. Societal and Economic Transformation of Asia at ECIPE.

Deringer, H., Lee-Makiyama, H., \& Murty, D. (2019). Europe and South-East Asia: Shifting from Diplomacy to Unilateralism. Societal and Economic Transformation of Asia.

Dewi, R. (2013). Implementasi Renewable Energy Directive Uni Eropa Sebagai Hambatan Non Tarif Perdagangan. Interdependence Journal Hubungan Internasional, 150.

Dewi, R. (2013, Mei-Agustus). Implementasi Renewable Energy Directive Uni Eropa Sebagai Hambatan Non Tarif Perdagangan. Interdependence Journal Hubungan Internasional, 150.

EEAS, E. E. (2013). Isu-Isu Kebijakan Perdagangan. Retrieved January 2021, from Delegasi Uni Eropa untuk Indonesia dan Brunei Darussalam:

http://eeas.europa.eu/delegations/indonesia/eu_indonesia/trade_relation/trade _policy_issues/index_id.htm

Erickson, F. (2009). Green Protectionism in the European Union: How Europe's Biofuels Policy and the Renewable Energy Directive Violate WTO Commitments. ECIPE Occasional Paper.

Erixon, F. (2009). Green Protectionism in the European Union:How Europe's Biofuels Policy and the Renewable Energy. ECIPE OCCASIONAL PAPER, 2-31.

European Commission. (2018). Renewable Energy - Recast to 2030 (RED II). Brussels: European Commission.

Fischer, C., \& Meyer, T. (2020). Baptists and Bootleggers in the Biodiesel Trade: EUBiodiesel (Indonesia). World Trade Review.

Gilpin, R. (1987). The Political Economy of International Relations. New Jersey: Princeton University Press.

Hettne, B. (1993). Neo-Mercantilism:: The Pursuit of Regionness. Cooperation and Conflict. 1993;28(3):211-232., 211-232. 
ISCC. (2018, Oktober 07). Winners and losers from the proposed ban on palm oil. Retrieved Januari 22, 2021, from International Sustainability \& Carbon Certification: https://www.iscc-system.org/eco-business-winners-and-losersfrom-the-proposed-ban-on-palmoil/\#: :text=In\%20January\%2C\%20the\%20European\%20Parliament,in\%20mainly \%20Indonesia\%20and\%20Malaysia.\&text=First\%20of\%20all\%2C\%20the\%20expor ts,somewhat\%20and\%20so\%20w

Jefferson, N. (2019, May). EU's Palm Oil Challenge: How Should Singapore Respond? RSIS Commentary.

Kartika, I. T. (2016). Interaksi Kebijakan Renewable Energy Directive dan Kebijakan Indonesian Sustainable Palm Oil terhadap Ekspor Kelapa Sawit Indonesia ke Uni Eropa. Retrieved January 2021, from Universitas Hasanuddin: https://core.ac.uk/download/pdf/77626632.pdf

Lottici, M. V. (2014). "Green Trade Protectionism": An Analysis of Three New Issues that Affect Developing Countries. Chinese Journal of Urban and Environmental Studies Vol. 02 , No. 02.

$\mathrm{Ng}$, J. (2019, May 10). EU's Palm Oil Challenge: How Should Singapore Respond? RSIS Commentary.

Purba, H. J., Sinaga, B. M., Novianti, T., \& Kustiari, R. (2018, September). DAMPAK KEBIJAKAN PERDAGANGAN TERHADAP PENGEMBANGAN INDUSTRI BIODIESEL INDONESIA. Jurnal Agro Ekonomi, 36, 51-74.

Roda, J.-M. (2019, Juli 08). The geopolitics of palm oil and deforestation. Retrieved Januari 22, 2021, from The Jakarta Post: https://www.thejakartapost.com/academia/2019/07/08/the-geopolitics-of-palmoil-and-deforestation.html

Russell, M. (2020). Palm oil: Economic and environmental impacts. Strasbourg: European Parliamentary Research Service.

Suwarno, W. (2019, April-September). Kebijakan Sawit Uni Eropa dan Tantangan bagi Diplomasi Ekonomi Indonesia. Jurnal Hubungan Internasional.

Wahab, A. (2013). Ekonomi Internasional. Alauddin University Press.

Wahyudi, H. (2019). PENGGUNAAN RENEWABLE ENERGY DIRECTIVE OLEH UNI EROPA UNTUK MENEKANKAN PENOLAKAN IMPOR CRUDE PALM OIL INDONESIA. Jurnal Dinamika Pemerintahan , 93. 